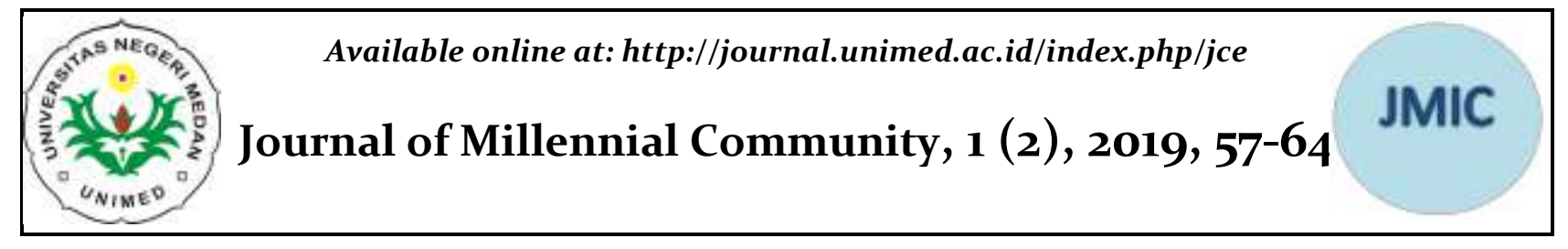

\title{
Faktor-faktor yang Mempengaruhi Ketidakberhasilan Program Keluarga Berencana di Desa Siaro Kecamatan Siborongborong
}

\author{
Sani Susanti', Reka Hutasoit ${ }^{2}$ \\ ${ }^{12}$ Universitas Negeri Medan \\ Susanti.sani@gmail.com
}

\begin{abstract}
Abstrak
Penelitian ini bertujuan untuk mengetahui faktor-faktor yang mempengaruhi ketidakberhasilan program Keluarga Berencana di Desa Siaro Kecamatan Siborongborong. Jenis penelitian yang digunakan dalam penelitian ini adalah deskriptif kuantitatif. Sampel yang diambil dari penelitian ini sebanyak 60 KK/PUS yang bertempat tinggal di Desa Siaro. Dalam penelitian ini, peneliti menggunakan pengumpulan data dengan menggunakan metode Questions (angket). Teknik analisis data menggunakan Uji Kecenderungan. Hasil penelitian yang diperoleh bahwa faktor-faktor yang mempengaruhi ketidakberhasilan program keluarga berencana dapat dilihat dari dua faktor yaitu faktor internal dan faktor eksternal. faktor internal yaitu: tentang pengetahuan akseptor kategori kurang dengan skor $50 \%$, dari segi jumlah anak kategori tinggi dengan perolehan skor $41,6 \%$, ditinjau dari segi kesehatan kategori cukup dengan skor sebesar 33,3\%, dan dari segi perolehan informasi dengan kategori kurang skor 31,6\%. Dan dilihat dari uji kecenderungan pada subvariabel faktor Eksternal yaitu: tentang dukungan suami dengan kategori cukup dengan perolehan skor $43,3 \%$, dari segi dukungan tenaga dengan kategori cukup dengan perolehan skor $50 \%$, dan dari segi sosial budaya dengan kategori cukup dengan perolehan skor 46,6\%.
\end{abstract}

Kata Kunci: Keluarga berencana, Pendidikan, Ketidakberhasilan program

\section{Factors Affecting the Unfailure of the Family Planning Program in Siaro Village, Siborongborong District}

\begin{abstract}
This study aims to determine the factors that influence the failure of the Family Planning program in Siaro Village, Siborongborong District. This type of research used in this research is quantitative descriptive. Samples taken from this study were $60 \mathrm{KK} / \mathrm{EFAs}$ residing in Siaro Village. In this study, researchers used data collection using the Questions (questionnaire) method. The data analysis technique used the Tendency Test. The research results obtained that the factors that influence the failure of family planning programs can be seen from two factors, namely internal factors and external factors. internal factors, namely: knowledge of acceptors of less categories with a score of $50 \%$, in terms of the number of children in the high category with the acquisition of a score of $41.6 \%$, in terms of health the category is sufficient with a score of $33.3 \%$, and in terms of the acquisition of information with the category of less a score of $31.6 \%$. And seen from the tendency test on External Factors subvariable, namely: about the support of the husband with a sufficient category with the acquisition of a score of $43.3 \%$, in terms of energy support with a sufficient category with the acquisition of a score of $50 \%$, and in terms of socio-cultural with a sufficient category with the acquisition of a score of $466 \%$.
\end{abstract}

Keywords: Family planning, education, program failure 


\section{PENDAHULUAN}

Indonesia sebagai salah satu negara berkembang yang tidak luput dari masalah kependudukan. Secaragaris besar, masalah pokok dibidang kependudukan yang dihadapi Indonesia antara lain jumlah penduduk yang besar dengan laju pertumbuhan penduduk yang relatif tinggi. Program Keluarga Berencana di Indonesia sudah dimulai sejak tahun 1957, namun masih menjadi urusan kesehatan dan belum menjadi urusan kependudukan. Namun sejalan dengan semakin meningkatnya jumlah penduduk Indonesia serta tingginya angka kematian ibu dan kebutuhan akan kesehatan reproduksi, program Keluarga Berencana selanjutnya digunakan sebagai salah satu cara untuk menekan pertumbuhan jumlah penduduk serta meningkatkan kesehatan ibu dan anak. Keluarga Berencana bertujuan untuk mewujudkan keluarga berkualitas melalui promosi, perlindungan dan bantuan dalam mewujudkan hak-hak reproduksi serta menyelenggarakan pelayanan, pengaturan dan dukungan yang diperlukan untuk membentuk keluarga dengan usia kawin yang ideal, mengatur jumlah, jarak, dan usia ideal anak, mengatur kehamilan, membina ketahanan dan kesejahteraan keluarga (Buku Panduan Promosi dan Konseling Kesehatan Reproduksi dalam Program Kependudukan, Keluarga Berencana dan Pembangunan manusia, Perwakilan BKKBN 2015).

Menurut Badan Pusat Statistik, jumlah penduduk di Indonesia tahun 2010 adalah 237.641.326 jiwa. Penghitungan jumlah penduduk dilakukan setiap 10 tahun sekali, artinya Badan Pusat Statistik akan melakukan sensus penduduk pada tahun 2020 mendatang. Jumlah penduduk
Indonesia pada tahun 2015, berdasarkan hasil sensus penduduk sebanyak 254,9 juta jiwa, yang terdiri dari 128,1 juta jiwa laki-laki dan 126,8 juta jiwa perempuan. Selain itu, BPS menunjukkan rasio jenis Page $\mid 58$ kelamin penduduk Indonesia yaitu sebesar 101.02 dan 101. Rasio jenis kelamin, BPS menunjukkan bahwa dari 100 penduduk perempuan dan 101 penduduk laki-laki. Adapun komposisi penduduk kota atau desa menunjukkan penduduk Indonesia pada 2015 lebih banyak di pedesaan, yakni 128,5 juta jiwa. Sementara di perkotaan besar sebanyak 126,3 juta jiwa. Meskipun jumlah penduduk di pedesaan lebih besar, pertambahan penduduk dari tahun 2014 ke 2015 di perkotaan lebih besar dibandingkan dengan pedesaan. Tercatat pertambahan penduduk di perkotaaan mencapai $1,75 \%$ sementara di pedesaan $0,52 \%$ (BPS,2015).

Salah satu usaha yang dilakukan pemerintah untuk menekan laju pertumbuhan penduduk melalui sistem bidang kesehatan adalah membangun keluarga sejahtera yaitu meningkatkan jumlah keluarga kecil yang bahagia dan sejahtera dengan memiliki 2 anak cukup. Pembangunan keluarga sejahtera diarahkan kepada terwujudnya nilai-nilai luhur budaya bangsa guna meningkatkan kesejahteraan keluarga dan membina keluarga agar mampu mendukung kegiatan pembangunan. Untuk itu perlu ditumbuhkan kesadaran masyarakat akan pentingnya norma keluarga kecil bahagia sejahtera yang dilandasi oleh rasa tanggungjawab, kesukarelaan, nilai-nilai agama dan luhur budaya bangsa. Usaha mewujudkan tujuan tersebut salah satunya melalui ikut program Keluarga Berencana. (Depkes RI,2006).

Karena itu pemerintah berusaha terus menekan angka pertumbuhan penduduk melalui berbagai cara, seperti menciptakan undang-undang perkawinan yang memperkenankan penduduk menikah pada usia 21 tahun, dan berbagai usaha lain yang mampu menekan laju pertumbuhan penduduk. Untuk 
menciptakan keluarga kecil bahagia dan sejahtera, maka kesadaran pasangan (suami-istri) sangat diperlukan, mereka adalah pasangan yang berada dalam jangka usia subur, yaitu baru memulai kehidupan keluarga. Pasangan Usia Subur (PUS) adalah pasangan dimana istrinya berusia 15-49 tahun (BKKBN,2007:8).

Ada beberapa aspek untuk mengukur tingkat kesejahteraan dalam suatu keluarga, yaitu sandang, pangan, kesehatan, pendidikan, agama, keluarga berencana, interaksi dalam keluarga, interaksi dalam lingkungan, informasi, dan transportasi. Semakin banyak aspek yang terpenuhi maka tingkat kesejahteraan semakin tinggi dan sebaliknya. (BKKBN, Hallasson, 2011).

Program keluarga berencana yang sudah dimulai sejak tahun 1957 yang bertujuan untuk meningkatkan derajat kesehatan dan kesejahteraan ibu dan anak, keluarga serta masyarakat pada umumnya. Berhasilnya pelaksanaan keluarga berencana diharapkan angka kelahiran dapat diturunkan, sehingga tingkat laju perkembangan penduduk tidak melebihi kemampuan kenaikan produksi, dengan demikian taraf kehidupan dan kesejahteraan rakyat diharapkan lebih meningkat.

Berdasarkan hasil pendataan tahun 2014-2015 pencapaian akseptor baru sangat rendah, yaitu $17,7 \%$ diakibatkan sudah adanya beberapa masyarakat yang sadar arti pentingnya norma keluarga sejahtera dan bahagia dan pendidikan yang mendukung sedangkan yang tidak menggunakan $82,3 \%$ diakibatkan masih eratnya budaya yang diyakini bahwa banyak anak akan membawa rejeki dan tingkat pendidikan yang rendah, dari pasangan usia subur target nasional yang dicapai adalah sebesar 60,88 \% (BPS, 2015).

Jumlah akseptor baru program Keluarga Berencana ditingkatkan setiap tahun. Pembinaan akseptor-akseptor yang ada dipergiat untuk menjaga kelangsungannya. Peningkatan sasaran ini membutuhkan peningkatan kemampuan organisasi dan administrasi pelaksanaan.
Selain dari pada itu kegiatan-kegiatan pelayanan medis, penerangan dan motivasi, pendidikan dan latihan, serta penelitian ditingkatkan. Namun demikian, usaha pencapaian program Keluarga Berencana diberbagai wilayah tidak selalu berhasil. Berbagai kendala dirasakan, selain dari pihak pemerintah, kendala datang dari kondisi sosial masyarakat. Kurangnya minat pasangan usia subur (PUS) dalam mengikuti Program Keluarga Berencana ditemukan di Desa Siaro Kecamatan Siborongborong, rata-rata masyarakat memiliki jumlah anak 5-6 orang, banyak ibu rumah tangga yang hamil pada usia 45 tahun keatas. Memiliki jumlah anak banyak sudah menjadi tradisi di Desa Siaro meskipun jika dilihat dari segi kesehatan/usia untuk hamil tidak diperbolehkan lagi, tetapi banyak ibu rumah tangga di Desa Siaro yang masih hamil pada usia rentan, tanpa memikirkan kondisi kesehatan. Berdasarkan hasil wawancara yang dilakukan peneliti dengan bidan Desa mengatakan bahwa ibu yang berusia 45 keatas sangat berpotensi pada kematian ibu dan anak, seperti yang terjadi pada bulan Januari lalu seorang ibu melahirkan dengan umur 49 tahun mengalami sakit parah setelah melahirkan (sumber Pustu Siaro).

Desa Siaro merupakan salah satu Desa di Kecamatan Siborongborong. Menurut data yang telah diperoleh dari kepala Desa Siaro Kecamatan Siborongborong terdapat $450 \mathrm{KK}$ dengan jumlah Pasangan Usia Subur (PUS) sebanyak 240 KK, 210 KK (lansia dan single parent). Pencapain ini masih belum sesuai target yang telah ditentukan pemerintah yang bertujuan untuk meningkatkan kesadaran PUS terhadap program Keluarga Berencana (KB) untuk menjamin kesehatan ibu dan anak serta kebahagiaan keluarga, (sumber kantor kepala Desa Siaro).

Hal ini ditandai oleh, banyak keluarga yang memiliki anak jumlahnya lebih dari 2 orang dalam setiap Pasangan Usia Subur (PUS), bahkan mencapai 5 sampai 6 orang anak. 


\section{METODE}

Dalam penelitian ini menggunakan pendekatan deskriptif kuantitatif. Adapun yang menjadi populasi dalam penelitian ini adalah pasangan usia subur yaitu sebanyak 240 orang. Untuk menentukan besarnya sampel, "apabila subjek lebih dari 100, lebih baik diambil semua sehingga penelitiannya penelitian populasi. Jika subjeknya lebih dari 100 maka dapat diambil $10-15 \%$ atau 20 25\%". (Arikunto,2010:43). Maka dalam penelitian ini penulis mengambil $25 \%$ PUS yaitu sebanyak $60 \mathrm{KK}$.

Teknik pengumpulan data yang digunakan ialah angket, Untuk memperoleh data tentang faktor yang mempengaruhi ketidakberhasilan program keluarga berencana, peneliti menggunakan angket (kuisioner) yang disebarkan kepada masyarakat yang terlibat sebagai sampel. Jenis angket yang disebarkan kepada responden adalah angket tertutup. dengan menggunakan skala likert, Kuesioner disusun oleh peneliti sebanyak 30 pertanyaan, tiap pertanyaan dengan option berjumlah 4 yaitu: jawaban SS (Sangat Setuju) dengan skor 4, jawaban S (setuju) skor 3, pilihan jawaban TS (Tidak Setuju) dengan skor 2, dan piihan jawaban STS (Sangat Tidak Setuju) diberi skor 1.

Proses analisis data dimulai dengan menelaah seluruh data yang diperoleh melalui hasil kuesioner. Setelah pengumpulan dan perolehan data dilaksanakan, maka data tersebut dianalisis dengan teknik analisa non statistik, karena penelitian ini bersifat deskriptif jadi dilakukan analisis data dengan persentase. Dalam penelitian ini, peneliti menggunakan uji kecenderungan untuk menginterpretasikan data. Uji kecenderungan dilakukan untuk mengetahui gambaran umum variabel. Langkah yang dilakukan yaitu dengan cara menaksir rata-rata skor yang diperoleh dibandingkan dengan skor ideal untuk selanjutnya. Interval skor yang didapatkan kemudian Page |60 dikategorikan dalam interpretasi tertentu. Lokasi Penelitian ini dilakukan di Desa Siaro Kecamatan Siborongborong Kabupaten Tapanuli Utara.

\section{PEMBAHASAN}

Setelah dilakukan penyebaran angket tentang faktor-faktor yang mempengaruhi ketidakberhasilan program keluarga berencana di Desa siaro kecamatan siborongborong, maka hasil sebaran angket dapat dilihat dari analisa data sebagai berikut dengan menggunakan rumus :

$$
P=F / N \times 100 \%
$$

Keterangan :

$\mathrm{P}=$ Jumlah keseluruhan respondensi

$\mathrm{F}=$ Frekwensi jawaban Individu (Responden)

$\mathrm{N}=$ Jumlah keseluruhan respondensi

Hasil penelitian melalui penyebaran angket diklasifikasikan berdasarkan data dari faktor internal yaitu :

\section{Pengetahuan Akseptor}

Pengetahuan akseptor dapat diartikan sebagai hasil tahu dan terjadi setelah orang melakukan penginderaan terhadap objek tertentu. Dan umumnya datang dari informasi yang disampaikan orang lain, dapat diperoleh dari buku, surat kabar, media massa, elektronik (Notoatmodjo, 2013). Dari hasil penelitian tentang pengetahuan akseptor dapat disimpulkan pada tabel di bawah ini. 
Journal of Millennial Community, 1 (2), September 2019

Sani Susanti, Reka hutasoit

Tabel 1. Program keluarga berencana dapat meningkatkan derajat kesehatan ibu serta menjamin keluarga sehat dan sejahtera.

\begin{tabular}{clcc}
\hline No & $\begin{array}{c}\text { Alternatif } \\
\text { Jawaban }\end{array}$ & F & \% \\
\hline 1 & Sangat Setuju & 17 & $28,33 \%$ \\
2 & Setuju & 38 & $63,33 \%$ \\
3 & Tidak Setuju & 5 & $8,33 \%$ \\
4 & Sangat Tidak & - & - \\
& Setuju & & \\
$\quad$ Jumlah & 60 & $100 \%$ \\
\hline
\end{tabular}

Berdasarkan tabel di atas diketahui bahwa sebanyak 17 responden $(28,33 \%)$ memilih sangat setuju, 38 responden $(63,33 \%)$ memilih setuju dan 5 responden $(8,33 \%)$ memilih tidak setuju, dan 0 responden memilih sangat tidak setuju. Dari data di atas dapat disimpulkan bahwa 38 responden $(63,33 \%)$ mengatakan setuju. Hal ini berarti bahwa mereka mengetahui pengetahuan akseptor dalam program keluarga berencana dapat meningkatkan derajat kesehatan ibu serta menjamin keluarga sehat dan sejahtera.

\section{Jumlah Anak}

Salah satu faktor yang menentukan keikutsertaan pangsangan suami istri dalam gerakan keluarga berencana adalah banyaknya anak yang dimilikinya. BKKBN (2008) menerangkan bahwa yang dimaksud keluarga kecil adalah keluarga yang jumlah anaknya paling banyak dua orang. Sedangkan keluarga besar adalah suatu keluarga dengan lebih dari dua orang anak. Dari hasil penelitian tentang penjumlah anak dapat disimpulkan pada tabel berikut ini:
Tabel 2. Memiliki 2 orang anak sudah cukup laki-laki maupun perempuan sama saja

\begin{tabular}{llcc}
\hline No & $\begin{array}{c}\text { Alternatif } \\
\text { Jawaban }\end{array}$ & F & $\%$ \\
\cline { 2 - 3 } 1 & Sangat Setuju & - & - \\
2 & Setuju & 18 & $30 \%$ \\
3 & Tidak Setuju & 28 & $46,66 \%$ \\
4 & Sangat Tidak & 14 & $23,3 \%$ \\
& $\begin{array}{l}\text { Setuju } \\
\text { Jumlah }\end{array}$ & 60 & $100 \%$ \\
\hline
\end{tabular}

Berdasarkan tabel di atas diketahui bahwa sebanyak 0 responden memilih sangat setuju, 18 responden (30\%) memilih setuju, 28 responden $(46,66 \%)$ memilih tidak setuju dan 14 responden $(23,3 \%)$ memilih sangat tidak setuju. Dari tabel di atas dapat disimpulkan bahwa Memiliki 2 orang anak sudah cukup laki-laki maupun perempuan sama saja, responden tertinggi memilih option tidak setuju yaitu sebanyak 28 responden $(46,66 \%)$. Hal ini berarti bahwa kebanyak masyarakat tidak merasa puas apabila memiliki dua anak.

\section{Kondisi Kesehatan}

Kondisi kesehatan dapat diartikan sebagai salah satu faktor penentu keikutsertaan istri dalam menggunakan alat kontrasepsi keluarga berencana, kondisi yang siap dan sehat secara mental juga harus diperhatikan, sebab apabila si ibu memiliki ketidakcocokan dalam menggunakan kontrasepsi maka tidak diperbolehkan untuk menggunakannya. Menurut data yang diperoleh tentang kondisi kesehatan, maka dapat disimpulkan dalam tabel berikut ini. 
Tabel 3.Tidak semua alat kontrasepsi diterima oleh tubuh, karena sebagian ibu mempunyai riwayat alergi dalam tubuhnya.

\begin{tabular}{llcc}
\hline No & $\begin{array}{c}\text { Alternatif } \\
\text { Jawaban }\end{array}$ & F & \% \\
\hline 1 & Sangat Setuju & 8 & $13,33 \%$ \\
2 & Setuju & 31 & $51,66 \%$ \\
3 & Tidak Setuju & 14 & $23,33 \%$ \\
4 & Sangat Tidak & 7 & $11,66 \%$ \\
& $\begin{array}{l}\text { Setuju } \\
\text { Jumlah }\end{array}$ & 60 & $100 \%$ \\
\hline
\end{tabular}

Berdasarkan tabel di atas diketahui bahwa sebanyak 8 responden $(13,33 \%)$ memilih sangat setuju, 31 responden $(51,66 \%)$ memilih setuju, 14 responden $(23,33 \%)$ memilih tidak setuju dan 7 responden $(11,66 \%)$ memilih sangat tidak setuju. Dari tabel di atas dapat disimpulkan bahwa tidak semua alat kontrasepsi diterima oleh tubuh, karena sebagian ibu mempunyai riwayat alergi dalam tubuhnya, responden tertinggi memilih option setuju yaitu sebanyakk 31 responden $(51,66 \%)$. Hal ini terdapat pada mereka yang menggunakan bahwa tidak semua alat kontrasepsi dapat diterima oleh tubuhnya.

\section{Informasi}

Informasi adalah sekumpulan data yang telah diproses dan dikelola sedemikian rupa sehingga menjadi sesuatu yang mudah dimengerti dan bermanfaat bagi penerima (Reymond Mcleod). Maka dari itu faktor penentu keikutsertaan masyarakat terletak kepada informasi yang didapatkannya. Dari hasil penelitian tentang informasi dapat disimpulkan pada tabel di bawah ini:
Tabel 4. Penggunaan alat kontrasepsi mempunyai dampak positif, misalnya mengatur jarak anak.

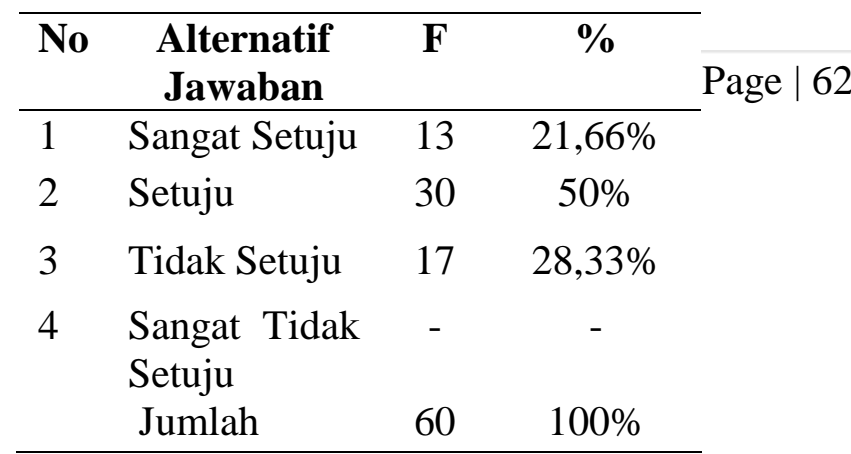

Berdasarkan tabel di atas diketahui bahwa sebanyak 13 responden $(21,66 \%)$ memilih sangat setuju, 30 responden $(50 \%)$ memilih setuju, 17 responden $(28,33 \%)$ memilih tidak setuju dan 0 responden $(0 \%)$ memilih sangat tidak setuju. Dari tabel di atas dapat disimpulkan bahwa Penggunaan alat kontrasepsi mempunyai dampak positf, misalnya mengatur jarak anak, responden tertinggi memilih pada option setuju yaitu sebanyak 30 responden (50\%). Hal ini berarti bahwa mereka mengetahui bahwa penggunaan alat kontrasepsi mempunyai dampak positif, dalam mengatur jarak anak. Dilihat dari hasil uji kecenderungan subvariabel faktor internal (Pengetahuan Akseptor, jumlah anak, kondisi kesehatan, dan informasi) di Desa Siaro Kecamatan Siborongborong pada kategori tinggi dengan rentang skor 49,4 keatas sebesar 16,6 \%, kategori cukup dengan rentang skor 44-49,4 sebesar $16,6 \%$, kategori kurang dengan rentang skor $\leq 38,6-44$ sebesar $46,6 \%$, dan kategori rendah dengan rentang skor $\geq 33,2-44$ sebesar $20 \%$. 
Berdasarkan hasil uji kecenderungan dapat disimpulkan bahwa pengetahuan responden terhadap faktor internal cenderung Kurang baik. Dikatakan kurang baik hal ini terlihat dari masih banyaknya masyarakat di Desa Siaro kurang peduli terhadap program keluarga berencana.

Berdasarkan

hasil

kecenderungan subvariabel faktor eksternal (dukungan suami, dukungan tenaga kesehatan, dan sosial budaya) di Desa Siaro Kecamatan Siborongborong pada kategori tinggi dengan rentang skor 37,9 keatas sebesar 33,3\%, kategori cukup dengan rentang skor 34-37,9 sebesar $51,6 \%$, kategori kurang dengan rentang skor $\leq 30,1-34$ sebesar 10,6 $\%$, kategori rendah dengan rentang skor $\geq 26,2-34$ sebesar $15 \%$. Berdasarkan hasil uji kecenderungan di atas dapat disimpulkan bahwa pengetahuan responden terhadap faktor Eksternal cenderung cukup. karena dalam faktor eksternal masyarakat kurang memberi perhatian terhadap kegiatan-kegiatan yang mendukung adanya program Keluarga berencana.

\section{KESIMPULAN}

Berdasarkan

hasil uji

kecenderungan subvariabel faktor internal (Pengetahuan Akseptor, jumlah anak, kondisi kesehatan, dan informasi) di Desa Siaro Kecamatan Siborongborong, dapat dikategorikan kurang baik. Dikatakan kurang baik karena hal ini terlihat dari masih banyaknya masyarakat di Desa Siaro kurang peduli terhadap program keluarga berencana. Dilihat dari hasil uji kecenderungan subvariabel faktor eksternal (dukungan suami, dukungan tenaga kesehatan, dan sosial budaya) di Desa Siaro Kecamatan Siborongborong, dapat dikategorikan cenderung cukup. Dikatakan kategori cukup karena dalam faktor eksternal masyarakat kurang memberi perhatian terhadap kegiatan-kegiatan yang Page 63 mendukung adanya program Keluarga berencana

\section{DAFTAR PUSTAKA}

Arikunto. 2006. Prosedur Penelitian Suatu Pendekatan Praktik. Jakarta : Rineka Cipta

Arikunto. $2010 . \quad$ Prosedur Penelitian,Suatu Pendekatan Praktek. Edisi Revisi V. Jakarta: Rineka Cipta

Basuki, Sulistyo. 2006. Metode Penelitian. Jakarta: Penaku

BKKBN. 2006. Buku Saku Bagi Petugas Lapangan Program KB Nasional, Materi Konseling. Jakarta: BKKBN

BKKBN. 2013. Pemantauan Pasangan Usia Subur Melalui Mini Survei Indonesia. Jakarta: BKKBN

BKKBN. 2015. Buku Panduan Promosi dan Konseling Kesehatan Reproduksi dalamProgram Kependudukan. Jakarta: 2015

BKKBN Sumatera Utara. 2008. Pedoman Operasional Program Ketahanankeluarga. Medan: BKKBN

Handayani, S. 2010. Buku Ajaran Pelayanan keluarga Berencana. Yogyakarta:Pustaka Rihama 
Hartono, H. 2002. Keluarga Berencana dan Kontrasepsi. Jakarta: Pustaka Sinar Harapan

Iqbal, Hasan. 2006. Analisis Data Penelitian dengan Statistik. Bumi Aksara: Jakarta

Irwan, M. (2017). Evaluasi program pelatihan keterampilan mengolah limbah kertas semen pada PKBM Cahaya Kota Binjai. JPPM (Jurnal Pendidikan dan Pemberdayaan Masyarakat), 4(2), 121-132.

Nora, F., \& Irwan, M. (2019). Empowerment On Climate Change: How Community Based Organizations Serving In Growing participation from society. Journal of Millennial Community, 1(1), 17-26. Retrieved from https://jurnal.unimed.ac.id /2012/index.php/jce/article/view $/ 12709$

Notoatmojo, S. 2007. Kesehatan Masyarakat IImu dan Seni. J akarta: Rineka Cipta

Suprian, A.S. 2005. EvaluasiPendidikan. Bandung : FPTK/UPI

Sugiyono.2014. Metode Penelitian Pendidikan; Pendekatan Kuantitatif, Kualitatif. Bandung: Alfabeta

Sugiyono.2010. MetodePenelitian; Kuantitatif, Kualitatif, danR\&D. Bandung: Alfabeta

Sugiyono.2017. MetodePenelitian; Kuantitatif, Kualitatif, danR\&D. Bandung: Alfabeta 